\title{
Review on Pharmacological Properties of Glory Lily (Gloriosa superba Linn.): An Endangered Medicinal Plant
}

\author{
B.A. Vaishnavi ${ }^{*}$, Hajira Khanm ${ }^{2}$ and H.R. Bhoomika ${ }^{3}$ \\ ${ }^{1}$ Department of Plantation, Spices, Medicinal and Aromatic Crops, \\ College of Horticulture, Hiriyur-577598, India \\ ${ }^{2}$ Department of Crop Physiology, GKVK, Bangalore, India \\ ${ }^{3}$ Department of Plantation, Spices, Medicinal and Aromatic Crops \\ College of Horticulture, Mudigere, University of Agricultural and Horticultural Sciences, \\ Shivamogga-577225, Karnataka India \\ *Corresponding author
}

\section{A B S T R A C T}

\section{Keywords}

Gloriosa superba, Chemical constituents,

Traditional uses, Pharmacological activities

Article Info

Accepted:

12 January 2019

Available Online:

10 February 2019
Glory lily is an important medicinal plant which comes under endangered species among the medicinal plants. In Southern India it is called as glory lily and climbing lily-in English. Seeds and tubers contain valuable alkaloids such as colchine and colchicoside, which are having ethnobotanical and pharmacological properties to cure various diseases. The tuber is used as an antidote for snake bites, gout, rheumatism, bruises, sprains, colic and chronic ulcers, haemorrhoids, cancer, impotence, nocturnal seminal emission, leprosy and also for including labour pains and abortions. Gloriosa superba also used in wounds, skin related problems, fever, inflammation, piles, blood disorders, uterine contractions, general body toner, poisoning. Roots are acrid, anthelmintic, antipyretic, bitter, digestive, expectorant, highly poisonous and promoting expulsion of the placenta. Root paste is effective against paralysis, rheumatism, snake bite and insect bites. Hence in this article an attempt has been made to gather the more information regarding pharmacological properties of glory lily.

\section{Introduction}

Gloriosa superb Linn. is an important medicinal plant belongs to the family colchicaceae or liliaceae. In English it is commonly called as glory lily, in Kannada gowri hoo, agnishike/ akkathangiballi while, in Hindi it is called karihari. Gloriosa is a native plant of Tropical Africa and it is found growing throughout tropical India, from the North-west Himalaya to Assam and the Deccan peninsula. In Karnataka, it is commonly found growing all along the Western Ghats and it is considered as the state flower of Tamil Nadu. All parts of the plant especially the tubers \& seeds contain 
alkaloids such as colchicine and Gloriosine (Trease and Evans, 1983). Tubers and seeds of Gloriosa superba are an expensive export commodity. In the Indian systems of medicine, the tubers are used as tonic, antiperiodic, antihelmintic and also against snake bites (Gupta et al., 2005). Colchicine \& Gloriosine are two commonly used phytochemicals for treatment of gout \& rheumatism. Different parts of the plant have wide variety of uses especially within traditional medicine practiced in tropical Africa and Asia. The tuber is used traditionally for the treatment of bruises and sprains, colic, chronic ulcers, haemorrhoids, cancer, impotence, nocturnal seminal emission, and leprosy and also for including labour pains and abortions (Kala et al., 2004). Gloriosa superba also used in wounds, skin related problems, fever, inflammation, piles, blood disorders, uterine contractions, general body toner, poisoning (Haroon et al., 2008). Glory lily gained the importance in medicine in recent years $\&$ is indicated promising drug for the production of colchicine on commercial scale.

\section{Plant Profile and Classification}

G. superba is a perennial herbaceous vine growing 3.5 to 6.0 meters in length. It bears V or L-shaped, finger-like tubers that are pure white when young, becoming brown with age. It is a climbing herb, sometimes erect up to 6 $\mathrm{m}$ long, bearing pointed, dark green, glossy leaves, each equipped with a tendril by means of which it clings onto other plants. Leaves occur in whorls of 3 to 4, opposite or alternate, simple, sessile, ovate to lanceolate ranging from 6 to $20 \mathrm{~cm}$ in length and 1.5 to 4 $\mathrm{cm}$ wide. The attractive flowers are borne on long stalks and have six erect petals ranging in colour from bright yellow to bicoloured, red and yellow or purple and yellow. The fruits are capsules that split open to release several smooth red seeds with a spongy test. (Maroyi et al., 2011)

\section{Habitat}

Gloriosa is a native of tropical Asia and Africa. The genus derives its name from the Latin word gloriosus, referring to the flowers. It is found growing throughout tropical India, from the North -West Himalayas to Assam and the Deccan peninsula. In Karnataka, it is commonly found growing all along the Western Ghats.

It is also found growing in Madagascar, Srilanka, Indo-China and on the adjacent island (Faroogi and Sreeramu, 2001). The plant grows in sandy-loam soil in the mixed deciduous forests in sunny positions. It is very tolerant of nutrient-poor soils. It occurs in thickets, forest edges and boundaries of cultivated areas in warm countries up to a height of $2530 \mathrm{~m}$. It is also widely grown as an ornamental plant in cool temperate countries under glass or in conservatories. (Acharya, 2006)

\section{Chemical Constitutes}

Studies reveal that all parts of the plant, especially the tubers are extremely toxic due to the presence of a highly active alkaloid, Colchicine. The species also contains another toxic alkaloid, Gloriosine. Other compounds such as lumicolchicine, 3-demethyl-Ndeformyl-N-deacetylcolchicine, 3demethylcolchicine, $\quad \mathrm{N}$-formyldeacetyl colchicine have been isolated from the plant (Jain and Suryavanshi, 2010)

\section{Traditional Uses}

Root tuber with sesamum oil will reduce the pain in arthritis affected joints (Abhishek et al., 2011). Traditionally, the rural women prefer $G$. superba plant for gynecological disorders like abortion, menstrual trouble, conception disorders, sterility, delivery problems etc., rather than modern medicines. 


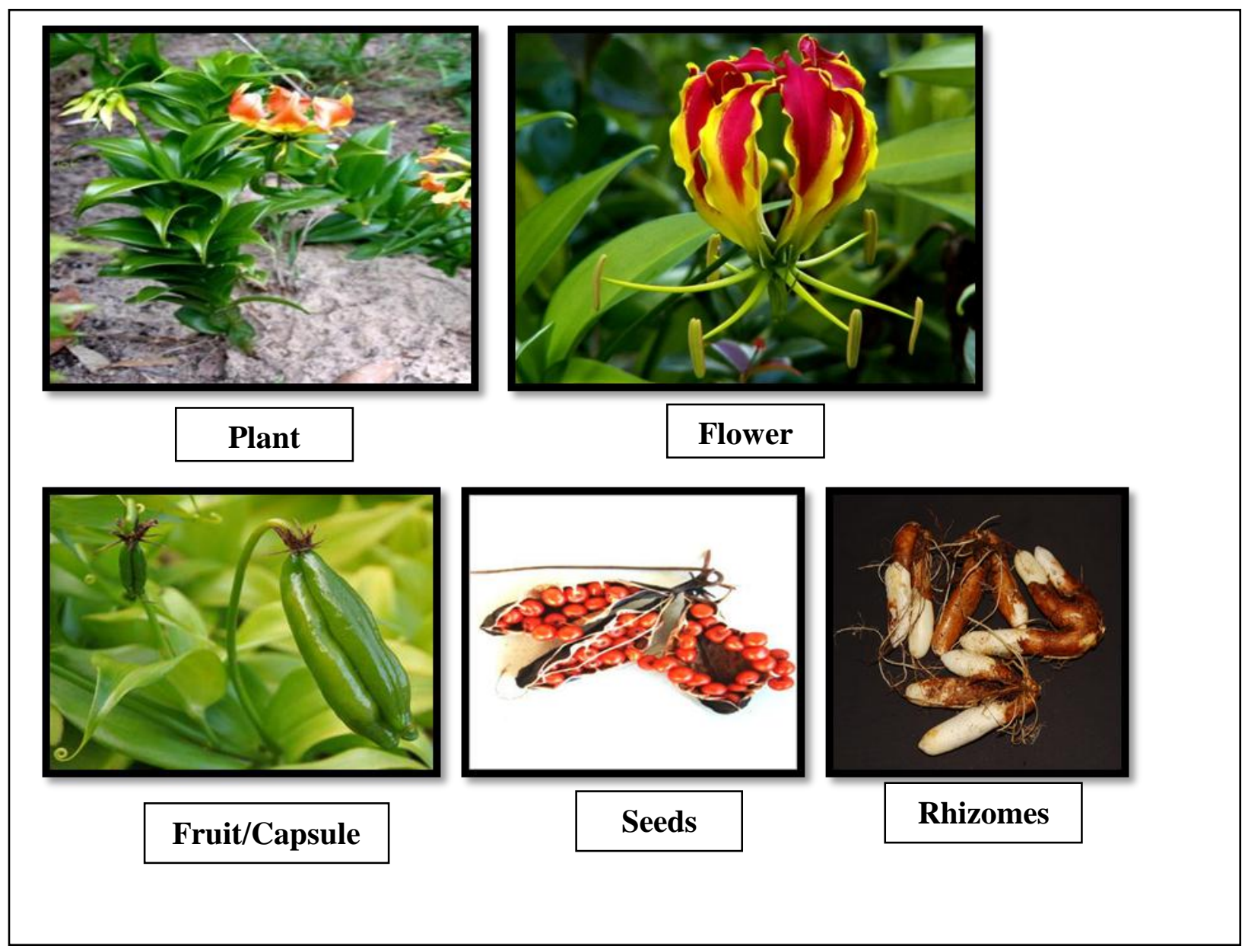

The Gond tribe of Madhya Pradesh in case of induced abortion they grind tuber of the plant mixed with ghee and used orally (Tiwari et $a l ., 2003)$. The tribes of Deogarh district used $G$. superba against piles. It is ethnomedicinally very important to the tribal's.

The people of this region derive immense benefit by using herbal medicines for their primary health care. The roots and rhizomes are used in traditional system of medicine. Rhizome is anticancerous, oxytocic, antimalarial, stomachic, purgative, cholagogue, anthelmintic, alterative, febrifuge and antileprotic. Leaf is antiasthmatic and antiinflammatory. Root shows antigonorrhoeic and antibiotic activity (Sahu, 2010)

\section{Pharmacological properties}

\section{Anti-anxiety}

Phytochemical screening of ethanolic and aqueous extracts showed presence of carbohydrates, alkaloids and saponins.

Amongst various extracts ethanolic extract of Gloriosa supberba Linn.

significantly increased mean number of entries and meantime spent by mice in open arms of elevated plus maze apparatus at the dose of $300 \mathrm{mg} / \mathrm{kg}$ with respect to control, thereby producing anti-anxiety activity (Sundaraganapathy et al., 2013). 


\section{Anti-bacterial property}

Both Gram positive and Gram negative bacteria growth was inhibited by the extracts. It may be due to the reason that the tubers have constant contact with soil. The plants are producing large number of organic compounds as secondary metabolites.

These compounds acts as chemotherapeutic, bactericidal and bacteriostatics. The extracts are prepared from the leaves and tubers are source of different secondary metabolites which may act in synergy to produce an increased activity against microbes that is in treatment of certain skin disease and infected wounds (Banu and Nagarajan, 2011).

\section{Anti-implantation or anti-fertility activity}

Oral administration of hydro alcoholic extract of G. superba at two different doses (30 and $60 \mathrm{mg} / \mathrm{kg}$ body wt) showed most significant dose dependent anti-fertility activity. The treated animals showed anti-implantation activity in postcoital study (administered from days 1 to 7 ).

After parturition, the number of litters born was significantly less than that of control. This study clearly reveals that the extract is effective before and after the implantation occurred. Hence, the drug indicated the highest anti-fertility activity (Latha et al., 2013)

\section{Anti-oxidant and anti-cancer activity}

The G. superba methanolic extracts reveals the presence of different types of phyto constituents which has the capacity of antioxidant and cytotoxicity effect on Hep-G2 cells (human liver cancer cells). Thus $G$. superba has the potentiality to inhibit the human carcinoma cell line growth (Simon and Jayakumar, 2016).

\section{Anticoagulant and antithrombotic activity}

The leaves extracts displayed anticoagulant properties by inhibiting thrombin induced clotting, with IC50 value of $2.97 \mathrm{mg} / \mathrm{ml} 21$ (Maroyi and Maesen, 2011)

\section{Anti-inflammatory activity}

Alcoholic, hydroalcoholic and aqueous extracts of $G$. superba tubers have been shown to have significant anti-inflammatory activity in male albino rats. According to these investigations, aqueous extract of 250 $\mathrm{mg} / \mathrm{kg}$ of $G$. superba tubers showed the best anti-inflammatory activity. Oral administration of colchicine at 2, 4 and 6 $\mathrm{mg} / \mathrm{kg}$ body weight resulted in 48.9, 68.7 and $79.1 \%$ inhibition respectively, while $30.9 \%$ inhibition was obtained in the phenylbutazone $100 \mathrm{mg} / \mathrm{kg}$ treated group once daily for a period of 4 days. These results clearly indicate that colchicine is more effective as an anti-inflammatory agent. (Maroyi and Maesen, 2011)

\section{Antidiabetic activity}

The phytochemical screening of G. superba revealed that it contains saponin glycosides, flavonoids, alkaloids, tannins and steroids. It has been previously documented that flavonoids and phenols are responsible for the hypoglycemic action. So, the anti-diabetic effect of the $G$. superba might be attributed to its flavonoid content (Thakur et al., 2015)

\section{Anthelmintic activity}

Bhushan and his co-workers conducted an experiment to know the anthelmintic activity of glory lily. In this study, earthworm lost their motility on exposure to crude extract of plant Gloriosa superba Linn. Each aqueous extract containing 30, 40, 50 and $60 \mathrm{mg} / \mathrm{mL}$ and alcoholic extract containing 20, 30, 40 
and $50 \mathrm{mg} / \mathrm{mL}$ produced dose dependent paralysis ranging from loss of motility to loss of response to external stimuli, which eventually progressed to death. From this study it is concluded that, all the extracts of whole plant of Gloriosa superba have potent anthelmintic activity when compared with conventionally used drug and is equipotent to standard anthelmintic drug (Bhushan et al., 2010).

\section{Uterotonic property}

Uterotonic assessment in-vitro and in-vivo of aqueous extract of $G$. superba was carried out in rats. Oxytocin was used as the standard uterotonic. Both the oxytocin and the extract produced dose dependent contractions (Roqaiya et al., 2015)

In conclusion, plants are natural sources of bioactive compounds to treat life threatening diseases. Gloriosa superba has showed various phytochemical properties, which can be used for treating various health ailments. Due to overexploitation of this plant is facing local extinction. Hence it is confirmed as an endangered plant by International Union for Conservation of Nature (IUCN). Therefore, there is a need to conserve this plant by in situ and ex situ multiplication in general and micro propagation.

\section{References}

Abhishek, M., Satish, K.V., Santosh, K.S., Deepika, M., Prasad, G.B.K.S. and Dua, V.K., 2011, Investigation of antiinflammatory properties of Swertia chirayta and Gloriosa superba. Recent Res. Sci. Technol., 3 (3): 40-43.

Acharya, D., Sancheti, G., Shrivastava, A., and Pawar, S., 2006, Rare Herb of Patalkot: Gloriosa superb. Traditional Herbs and Medicines, 10-24.

Banu, H.R. and Nagarajan, N., 2011,
Antibacterial potential of glory lily, Gloriosa superb Linn. Int. res. J. of Pharm., 2 (3) 139-142.

Faroogi and Sreeramu, 2001, Cultivation of Medicinal and Aromatic Crops, niversities press (India) private limited, Hyderabad, India, 108.

Frost, C.L., Kee NLA, Mnonopi, N., Davids, H. and Nande, R.J., 2008, Antithrombotic/anticoagulant and anticancer activities of selected medicinal plants from South Africa. African J. of Biotech., 7: 217-223.

Gupta, L.M., Rana, R.C., Raina, R. and Gupta, M., 2005, Colchicine contents in Gloriosa superba L. SKUAST-J., 4: 238-241.

Haroon, K., Murad, A.K., Tahira, M. and Muhammad, I.C. 2008, Antimicrobial activities of Gloriosa superba extracts. J. Enz. Inhibition Med. Chem., 22 (6): 722-725.

Jain, A.P., and Suryavanshi, S., 2010, G. superba linn. - A pharmacological review. Int. J. of Pharm. Res. and Development., 2 (8): 24-26.

Kala, C., Farooquee, N. and Dhar, U., 2004, Prioritization of medicinal plants on the basis of available knowledge, existing practices and use value status in Uttaranchal, India. Biodiver. Conserv. 13 (2): 453-469.

Latha, K.P., Kirana, H. and Girish, H.N., 2013, Anti- Implantation Activity of the Hydroalcoholic Tuber Extract of Gloriosa superba Linn in Female Albino Rats. Int. J. advances in Pahrm. Bio. And Chem., 2 (3): 443-448.

Maroyi and Maesen, 2011, Gloriosa superba L. (family Colchicaceae): Remedy or poison? Journal of Medicinal Plants Research, 5 (26): 6112-6121.

Pawar, B.M., Wavhal, V.P., Pawar, N.D., Agarwal, M.R., Shinde, P.B., and Kamble, H.V., 2010, International Journal of PharmTech Research, 2(2): 
1483-1487.

Roqaiya, M., Begum, W., Majeedi, S.F. and Saiyed, A., 2015, A Review on Herbs with Uterotonic Property. J. of Phytopharmacol., 4 (3): 190-196.

Sahu, S.C., Dhal, N.K. and Mohanty, R.C., 2010, Potential Medicinal Plants Used by the Tribal of Deogarh District, Orissa, India. Ethno. Med. 4 (1): 53-61.

Simon, S.E. and Jayakumar, F.A., 2016, Antioxidant Activity and Anticancer Study on Phytochemicals Extract from Tubers of Gloriosa superba against Human Cancer Cell (Hep-G2). J. of Pharmacog. \& Phytochem., 4 (4): 7-12.

Sundaraganapathy, R., Niraimathi, V., 2013, Thangadurai, A., Kamalakannan, D., Narasimhan, B. and Deep, A., Antianxiety activity of Gloriosa superba
Linn. Hygeia. J.D. Med., 5 (1) 150.

Thakur, V., Choudhary, M., Garg, A., Choudhary, N., Jangra, N., and Budhwar, V., 2015, Evaluation of a Hydroalcoholic Extract of the Leaves from the Endangered Medicinal Plant gloriosa superba linn. (colchicaceae) for its Potential Anti-diabetic Effect. Archive of med., 7 (8): 1-8.

Trease, S.E. and Evans, D., 1983, Colchicum seed and corn. In: Pharmacognosy, 12th edn. Balliere Tindall, London, pp. 593559.

Tiwari, D.K. and Yadav, A., 2003, Ethnobotanical Investigation of Some Medicinal Plants Availed by Gond Tribe of Naoradehi Wild Life Sanctuary, Madhya Pradesh, Anthropologist, 5(3): 201-202.

\section{How to cite this article:}

Vaishnavi, B.A., Hajira Khanm and Bhoomika, H.R. 2019. Review on Pharmacological Properties of Glory Lily (Gloriosa superba Linn.): An Endangered Medicinal Plant. Int.J.Curr.Microbiol.App.Sci. 8(02): 1359-1364. doi: https://doi.org/10.20546/ijcmas.2019.802.159 